\title{
PENGARUH PENILAIAN KINERJA DAN MOTIVASI TERHADAP PRODUKTIVITAS PEGAWAI PADA BADAN KEPEGAWAIAN DAERAH DAN PENGEMBANGAN SUMBER DAYA MANUSIA KEBUPATEN KEPAHIANG
}

\author{
Ermy Wijaya ${ }^{1)} \bullet$ Pipin Permata Sari ${ }^{2)}$ \\ Universitas Dehasen Bengkulu \\ Ermy.wijaya04@gmail.com \\ Pi2n.permat4@gmail.com
}

\begin{abstract}
The purpose of this study is to find out the effect of performance assessment and motivation on employee productivity in the Regional Personnel and the Human Resources Development of Kepahiang Regency. This type of research is quantitative research and causal research, because it proves the causal correlation influenced by the variables studied. Respondents in this study were civil servants from the Regional Personnel and the Human Resources Development of Kepahiang Regency, the samples were 32 people. Data collection techniques using questionnaires and the data obtained were analyzed using SPSS with partial correlation test, multiple regression test, statistical test ( $t$ test and $f$ test).The results showed that from the $t_{\text {test }}$ obtained tcount for the performance appraisal variable the motivational variable which means that there is a partial effect of performance appraisal $\left(X_{1}\right)$ and motivation $\left(X_{2}\right)$ on the productivity $(Y)$ of employees at the Regional Personnel Agency and the Human Resources Development of Kepahiang Regency. Based on the results of statistical tests, the calculated with a which means that there is an effect the effect of performance assessment and motivation on employee productivity in the Regional Personnel and the Human Resources Development of Kepahiang Regency. Value or This means that the contribution of the Performance Assessment $\left(X_{1}\right)$ and Motivation $\left(X_{2}\right)$ variables in influencing Employee Productivity $(Y)$ is influenced by other variables not examined in this study.
\end{abstract}

Keywords: Performance Assessment, Motivation, Productivity

\section{PENDAHULUAN}

Sumber daya manusia dalam suatu organsasi adalah suatu kesatuan yang tidak dapat dipisahkan. Organisasi akan berjalan sesuai dengan harapan dan tujuan apabilaterdapat manusia yang berkualitas dan memiliki tujuan yang sama yaitu ingin menjadikan tempat mereka bekerja mengalami peningkatan pendapatan dari masa kemasan. Apabila tujuan dan keinginan sudah dijalankan dan dapat diwujudkan, maka sumber daya manusia tersebut tentu berharap hasil pekerjaan dan jerih payahnya mendapat hasil yang sepadan dengan apa yang sudah mereka kerjakan selama ini. Selain itu untuk mewujudkan kinerja yang maksimal dari pegawai maka organisasi membutuhkan penilain kinerja pegawainya.

Badan Kepegawaian Daerah dan Pengembangan Sumber Daya Manusia adalah sebuah instansi pemerintah yang mempunyai tugas melaksanakan penyusunan dan pelaksanaan kebijakan daerah di bidang kepegawaian serta dapat ditugaskan untuk penyelenggaraan 
wewenang yang dilimpahkan oleh pemerintah kepada Walikota selaku wakil pemerintah dalam rangka dekonsentrasi. Sedangkan Badan Kepegawaian Daerah dan Pengembangan Sumber Daya Manusia Kabupaten Kepahiang yaitu merupakan Satuan Kerja Perangkat Daerah (SKPD) yang dibentuk berdasarkan Peraturan Daerah Kabupaten Kepahiang Nomor 14 Tahun 2007 tentang struktur organisasi perangkat daerah.

Menurut Kasmir (2018:184) penilaian merupakan suatu system yang dilakukan secara periodik untuk meninjau dan mengevaluasi kinerja individu.Penilaian kinerja merupakan suatu pedoman yang diharapkan dapat menunjukan prestasi kerja karyawan secara rutin dan teratur sehingga dapat memberikan manfaat bagi pemberian kompensasi dan pengembangan karir Karyawan.Menurut Rivai dan Basri (2017:83) penilaian kerja merupakan kajian sistematis tentang kondisi kerja karyawan yang dilaksanakan secara formal yang dikaitkan dengan standar kinerja yang telah ditentukan oleh perusahaan.

Dari beberapa pendapat diatas dapat disimpulkan bahwa penilaian kinerja yaitu penilaian terhadap hasil kerja individu atau pegawai yang dihasilkan dan dibandingkan dengan standar yang ada baik kualitas maupun kuantitas yang telah ditetapkan sebelumnya.Penilaian kinerja individu sangat bermanfaat bagi dinamika pertumbuhan organisasi secara keseluruhan, melalui penilaian tersebut maka dapat diketahui kondisi sebenarnya tentang bagaimana kinerja pegawai sehingga dapat merencanakan pengembaqngan karir lebih lanjut bagi pegawai yang bersangkutan. Dengan kata lain penilaian kinerja ini menilai dan mengevaluasi keterampilan, kemampuan, pencapaian serta pertumbuhan seorang pegawai.

Menurut Nirman (2005:47) Motivasi adalah keadaan dimana usaha dan kemauan keras seseorang diarahkan kepada pencapaian hasil tertentu, seperti produktivitas, kehadiran atau prilaku kerja kreatifnya sedangkan menurut Adair, Jhon (2007:192) Motivasi adalah apa yang membuat orang melakukan sesuatu dan juga dapat membuat orang benar-benar berusaha mengeluarkan energy demi apa yang mereka lakukan agar mencapai tujuan yang diinginkan.

Jadi dapat disimpulkan bahwa motivasi adalah sebuah dorongan atau alasan yang mendasari semangat dalam melakukan sesuatu dan pemberian motivasi ini diharapkan setiap individu pegawai mau bekerja keras dan antusias untuk mencapai presatasi kerja yang tinggi.

Menurut Blecher dalam Wibowo (2007-109) produltivitas adalah bahgaimana menghasilkan atau meningkatkan hasil barang setinggi mungkin dengan memanfaatkan sumber daya secara efisien. Oleh karena itu produktivitas sering diartikan sebagai rasio antara keluaran dan masukan dalam satuan waktu tertentu. Sedangkan menurut Wexley dalam Sedarmayanti (2009:65) bahwa produktivitas individu dapat dinilai dengan apa yang dilakukan oleh individu tersebut dalam kerjanya, dan produktivitas individu adalah bagaimana seseorang melaksanakan kerjanya (job performance)

Dapat disimpulkan pula bahwa produktivitas kerja adalah perbandingan antara hasil yang dicapai (output) dengan keseluruhan sumber daya yang digunakan (input). Produktivitas menunjukan hubungan antara keluaran yang ditimbulkan oleh system produksi atau jasa dan masukan yang disediakan untuk menciptakan keluaran tersebut.

Badan kepegawaian Daerah dan Pengembangan Sumber Daya Manusia adalah sebuah I stansi Pemerintah yang mempunyai tugas melaksanakan penyusunan dan pelaksanaan kebijakan daerah di bidang kepegawaian serta dapat ditugaskan untuk penyelenggaraan wewenang yang dilimpahkan oleh pemerintah kepada Walikota selaku wakil Pemerintah dalam rangka dekonsetrasi sedangkan Badan Kepegawaian Daerah dan pengembangan Sumber Daya manusia Kabupaten Kepahiang yaitu merupakan Satuan kerja Perangkat Daerah (SKPD) yang dibentuk 
berdasarkan Peraturan Daerah Kabupaten Kepahiang No.14 Tahun 2007 tentang Struktur Organisasi Perangkat Daerah.

Berdasarkan hasil pengamatan, peneliti menemukan bahwasanya terdapat kecendrungan menurunnya kinerja pegawai disebabkan karena kurang disiplinnya pegawai itu sendiri, pegawai tidak mengikuti prosedur kerja yang ada, pada jam kerja sering tidak ada ditempatnya dan juga terdapat pegawai yang datang terlambat. Hal ini dapat dilihat dari data yang diperoleh dari pihak perusahaan yang telah di lampirkan di lampiran 2 yang berisi daftar rekapitulasi kehadiran pegawai dalam kurun waktu 8 bulan (Januari-Agustus 2019) yang mana penilaian kinerja pada bulan Januari (3,10\%), Februari (2,84\%), Maret (2,81\%), April (2,76\%), Mei (2,75\%), Juni $(1,95 \%)$, Juli $(2,73 \%)$ dan Agustus $(2,73 \%)$ dari hasil persentase yang telah diolah dapat kita ketahui bahwa penilaian kinerja yang terjadi cenderung mengalami penurunan satiap bulannya. Berdasarkan uraian diatas, maka peneliti tertarik mengangkat judul "Pengaruh Penilaian Kinerja dan Motivasi terhadap Produktivitas Pegawai pada Badan Kepegawaian Daerah dan Pengembangan Sumber Daya Manusia Kebupaten Kepahiang”.

\section{LANDASANTEORI}

\section{Manajemen sumber Daya Manusia}

Manajemen sumber daya manusia adalah suatu proses menangani berbagai masalah pada ruang lingkup karyawan, pegawai, buruh, manajer, dan tenaga kerja lainnya untuk dapat menunjang aktifitas organisasi atau perusahaan demi mencapai tujuan yang telah ditentukan.

Menurut Kasmir (2018:6) manajemen sumber daya manusia adalah proses pengelolaan manusia, melalui perencanaan, rekrutmen, seleksi, pelatihan, pengembangan, pemberian kompensasi, karir, keselamatan dan kesehatan, serta menjaga hubungan industrial sampai pemutusan hubungan kerja guna mencapai tujuan perusahaan dan peningkatan kesejahteraan pegawai individu (stakeholder). Noe dalam Kasmir (2018:6) Menyebutkan bahwa manajemen sumber daya manusia merupakan bagaimana mempengaruhi perilaku, sikap dan kinerja karyawan, melaui kebijakan dan sistem yang dimiliki oleh perusahaan.

\section{Penilaian Kinerja}

Bahwa penilaian kinerja yaitu penilaian terhadap hasil kerja individu atau pegawai yang dihasilkan dan dibandingkan dengan standar yang ada baik kualitas maupun kuantitas yang telah ditetapkan sebelumnya. Penilaian kinerja individu sangat bermanfaat bagi dinamika pertumbuhan organisasi secara keseluruhan, melalui penilaian tersebut maka dapat diketahui kondisi sebenarnya tentang bagaimana kinerja pegawai sehingga dapat merencanakan pengembangan karir lebih lanjut bagi pegawai yang bersangkutan. Dengan kata lain penilaian kinerja ini menilai dan mengevaluasi keterampilan, kemampuan, pencapaian, serta pertumbuhan seorang pegawai.

Menurut Kasmir (2018:184) Penilaian kinerja merupakan suatu sistem yang dilakukan secara periodik untuk meninjau dan mengevaluasi kinerja individu. Penilaian kinerja merupakan suatu pedoman yang diharapkan dapat mewujudkan prestasi kerja para karyawan secara rutin dan teratur.Sehingga dapat memberikan manfaat bagi pemberian kompensasi dan pengembangan karir karyawan.

Menurut Rivai dan Basri dalam Waseso (2017:83) pemilaian kinerja merupakan kajian system tentang kondisi kerja karyawan yang dilaksanakan secara formal yang dikaitkan dengan standar kinerja yang telah ditentukan pleh perusahaan sedangkan menurut Hasibuan (2012:87) 
menyatakan bahwa penilaian kinerja adalah menilai rasio hasil kerja nyata dengan standar kualitas maupun kuantitas yang dihasilkan setiap pegawai.

Penilaian kinerja merupakan suatu proses yang dilakukan secara sistematis untuk menilai keseluruhan kinerja pegawai dalam jangka waktu atau periode tertentu. Kegunaan penilaian kinerja merupakan sebuah mekanisme yang dapat digunakan untuk memastikan apakah setiap karyawan pada tiap tingkatan telah menyelesaikan tugasnya sesuai demnga standar yang telah ditetapkan sebelumnya.

\section{Motivasi}

Motivasi adalah sebuah dorongan atau alasan yang mendasari semangat dalam melakukan sesuatu. Dengan kata lain motivasi adalah hal-hal yang menimbulkan dorongan, dan motivasi kerja adalah pendorong semangat yang menimbulkan suatu dorongan atau keinginan individu benar-benar berusaha dan mengeluarkan energi demi apa yang mereka lakukan. Pemberian motivasi ini diharapkan setiap individu pegawai mau bekerja keras dan antusias untuk mencapai prestasi kerja yang tinggi .

Istilah motivasi berasal dari kata latin "movere" yang berarti dorongan atau menggerakkan. Motivasi mempersoalkan bagaimana cara mengarahkan daya dan potensi agar bekerja mencapai tujuan yang ditentukan (Hasibuan, 2006:141).

Motivasi kinerja pegawai adalah sustu kebutuhan yang muncul dari dalam diri seorang pegawai yang dipengaruhi factor internal maupun eksternal untuk melakukan pekerjaan dengan di perusahaan. Teori kebutuhan yang berguna untuk memotivasi pegawai dalam bekerja menurut McClelland dalam Robbins dan Judge (2009:230) yang dimaksud adalah pencapaian kebutuhan kekuatan,kebutuhan pencapaian dan kebutuhan hubungan.

Teori Hierarki Maslow dalam Juniu (2017:74) mengemukakan bahwa kebutuhan kita terdiri dari lima katagori yaitu fisiologis, keselamatan atau keamanan, rasa memiliki atau social, penghargaan dan aktualisasi diri.

\section{Produktivitas}

Produktivitas kerja adalah perbandingan antara hasil yang dicapai (output) dengan keseluruhan sumber daya yang digunakan (input). Produktivitas menunjukan hubungan antara keluaran yang ditimbulkan oleh sistem produksi atau jasa dan masukan yang disediakan untuk menciptakan keluaran tersebut. Menurut Blecher dalam Wibowo (2007:109) produktivitas adalah bagaimana menghasilkan atau meningkatkan hasil barang setinggi mungkin dengan memanfaatkan sumber daya secara efesien.Oleh karena itu produktivitas sering diartikan sebagai rasio antara keluaran dan masukan dalam satuan waktu tertentu.

Menurut Sedarmayanti (2009:65) produktivitas kerja bukan semata-mata ditumjukan untuk mendapatkan hasil kerja sebanyak-banyaknya, melainkan kualitas untuk kerja juga penting diperhatikan, dengan kata lain produktivitas individu dapat dinilai dengan apa yang dilakukan oleh individu tersebut dalam kerjanya, dan produktivitas individu adalah bagimana seseorang melaksanakan kerjanya. Menurut Simanjuntak dalam Sutrisno (2017:103) ada beberapa factor yang mempengaruhi produktivitas karyawan yaitu pelatihan, mental dan kemampuan fisik karyawan serta hubungan antara atasan dan bahwahan.

Jadi dapat disimpulkan bahwa hubungan antara penilaian kerja adalah absensi dimana kejujuran,tanggungjawab,kemampuan,loyalitas,kepatuhan,kerjasama,kepemimpinan. Motivasi adalah kebutuhan fisiologis, kebutuhan keamanan dan keselamatan, kebutuhan social,kebutuhan 
penghargaan serta kebutuhan aktualisasi diri sedangkan produktivitasnya adalah kuantitas kerja, dan kualitas kerja.

\section{Kerangka Analisis}

Gambar 1. Kerangka Analisis

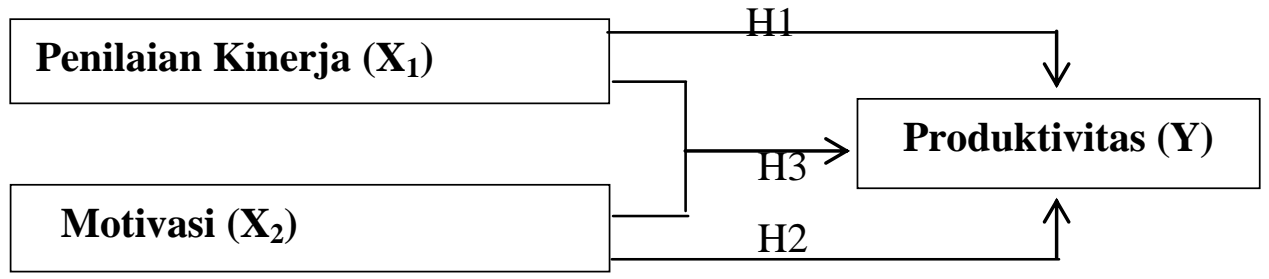

Keterangan :

- $\mathrm{X}_{1}, \mathrm{Y}$ : Penilaian kinerja dengan indikator (absensi, kejujuran, tanggung jawab, kemampuan, loyalitas, kepatuhan, kerja sama, kepemimpinan dan prakarsa) secara parsial berpengaruh terhadap produktivitas pegawai.

- $\mathrm{X}_{2}, \mathrm{Y}$ : Motivasi dengan indikator (kebutuhan fisiologis, kebutuhan keamanan dan keselamatan, kebutuhan sosial, kebutuhan penghargaan, kebutuhan aktualisasi diri) secara parsial berpengaruh terhadap produktivitas pegawai.

- $\mathrm{X}_{1}, \mathrm{X}_{2}, \mathrm{Y}$ : Penilaian Kinerja dan motivasi secara bersama-sama berpengaruh terhadap produktivitas pegawai dengan indikator (kuantitas kerja, kualitas kerja dan ketepatan waktu).

Dari kerangka analisis diatas dapat dilihat yaitu :

Paradigma ganda dengan dua variabel independen $\mathrm{X}_{1}$ dan $\mathrm{X}_{2}$, dan satu variabel dependen $\mathrm{Y}$, mencari hubungan antara $\mathrm{X}_{1}$ dengan $\mathrm{Y}$ dan $\mathrm{X}_{2}$ dengan $\mathrm{Y}$ dan mecari hubungan $\mathrm{X}_{1}$ (penilaian kinerja) dan $\mathrm{X}_{2}$ (motivasi) secara bersama-sama terhadap $\mathrm{Y}$ (Produktivitas pegawai).

\section{Hipotesis}

$\mathrm{H} 1$ : Diduga penilaian kinerja $\left(\mathrm{X}_{1}\right)$ berpengaruh positif dan signifikan terhadap produktivitas pegawai (Y) pada Badan Kepegawaian Daerah dan Pengembangan Sumber Daya Manusia Kabupaten Kepahiang.

$\mathrm{H} 2$ : Diduga motivasi $\left(\mathrm{X}_{2}\right)$ berpengaruh positif dan signifikan terhadap produktivitas pegawai (Y) pada Badan Kepegawaian Daerah dan Pengembangan Sumber Daya Manusia Kabupaten Kepahiang.

$\mathrm{H} 3$ : Diduga penilaian kinerja $\left(\mathrm{X}_{1}\right)$ dan motivasi $\left(\mathrm{X}_{2}\right)$ berpengaruh positif dan signifikan terhadap produktivitas pegawai (Y) pada Badan Kepegawaian Daerah dan Pengembangan Sumber Daya Manusia Kabupaten Kepahiang.

\section{METODOLOGI}

Penelitian ini termasuk penelitian kuantitatif, dimana data penelitian memuat angka-angka dan dianalisis menggunakan statistik (Sugiyono, 20013:13). Desain penelitian yang akan digunakan adalah riset kausal, karena akan membuktikan hubungan sebab akibat atau hubungan mempengaruhi atau dipengaruhi dari variabel-variabel yang diteliti, yaitu pengaruh penilaian 
kinerja dan motivasi terhadap produktivitas pegawai pada Badan Kepegawaian Daerah dan Pengemabangan Sumber Daya manusia Kabupaten Kepahiang. Sampel dalam penelitian ini menggunakan metode non Probability sampling yaitu dengan cara purposive sampling adalah tehnik pengambilan sampel sumber data dengan pertimbangan tertentu dengan cara menentukan target elemen populasi yang diperkirakan paling cocok untuk dikumpulkan datanya dan dijadikan sebagai anggota sampel. Populasi dalam penelitian ini diperoleh dari jumlah pegawai pada Badan Kepegawaian Daerah dan Pengembangan Sumber Daya Manusia Kabupaten Kepahiang yaitu 39 orang pegawai yang terdiri dari 32 pegawai PNS dan 7 orang pegawai Honorer. Dalam pengumpulan data peneliti menggunakan metode koesioner yaitu tehnik pengumpulan data yang dilakukan dengan cara memberi seperangkat pertanyaan kepada responden yang dilengkapi dengan beberapa alternative jawaban. Hasil jawaban responden terhadap koesioner yang diberikan skor jawaban, dimana skala yang digunakan adalah skala likert (Sugiyono 2013:134).

\section{Metode Analisis}

a. Uji Validitas

Uji validitas dilakukan untuk mengukur sah atau valid tidaknya suatu kuesioner,suatu kitem dikatakan valid jika pernyataan pada kuesioner mampu untuk mengungkapkan sesuatu yang akan diukur oleh koesioner tersebut agar data yang diperoleh bisa relevan dengan tujuan uji validitas yang digunakan adalah dengan cara menghitung korelasi antara skor masing-masing butir pertanyaan dengan skor setiap pertanyaannya.pengujian ini menggunakan metode pearson correlation dimana keberadaan hubungan antara variable $\mathrm{x}$ dan $\mathrm{y}$, jika korelasi skor masing-masing butir pernyataan setiak konstruknya akan dilkatakan valid apabila signifikan pada level 0,05

b. Uji Reabilitas

Uji Reabilitas adalah untuk mengukur sejauhmana pengukuran data dapat memberikan hasil relative konsisten atau tudak berbeda jika diukur ulang pada subjek yang sama sehingga dapat diketahui konsistensinya atau keterhadalannya ukur.Teknik ini digunakan dalam pengukuran realibilitas adalah teknik Cronchbach Alpha,dan pertanyaan yang akan diuji dikatakan reabel apabila cronchbach Alpha $>0,60$

c. Uji Linieritas

Bertujuan untuk mengetahui apakah dua variable mempunyai hubungan yang linier atau tidak secara signifikan. Uji ini biasanya digaunakan sebagai prasyarat dalam analisis korelasi atau regresi linier. Pengujian pada SPSS dengan menggunakan Test for linearity dengan pada taraf signifikan 0,05 . Dua variable dikatakan mempunyai hubungan yang linear bila signifiukan kurang dari 0,05

\section{Analisis Korelasi dan Regresi}

a. Analisis Korelasi Ganda

Analisis korelasi ganda didasari atas pengaruh satu variabel independen dengan satu variabel dependen. Menurut Sugiyono (2009: 261-262), Apabila analisis korelasi ganda sederhana didasari atas hubungan fungsional atau kausal satu variabel independen dengan satu variabel dependen, maka analisis korelasi ganda didasari atas hubungan fungsional atau kausal dua atau lebih variabel independen dengan satu variabel dependen. Pada 
penelitian ini ada dua variabel bebas sehingga menurut Sugiyono (2009: 275) persamaan korelasi ganda tersebut adalah:

$$
R_{y . x 1, x 2}=\sqrt{\frac{r_{y x 1}^{2}+r_{y x 1_{1}}^{2}-2 r_{y x 1} r_{y x 2} r_{x 1 x 2}}{1-r_{x 1 x 2}}}
$$

$R_{y . x 1, x 2}=$ Korelasi antara variabel X1 dan X2 secara bersama - sama dengan $\mathrm{Y}$

$r_{y x 1}=$ Korelasi antara variabel $\mathrm{X} 1$ dengan variabel $\mathrm{Y}$

$r_{y x 2}=$ Korelasi antara variabel $\mathrm{X} 2$ dengan variabel $\mathrm{Y}$

$r_{x 1 \times 2}=$ Korelasi antara variabel $\mathrm{X} 1$ dengan variabel X2

\section{b. Analisis Regresi Linier Berganda}

Karena dalam penelitian ini terdapat lebih dari satu variabel bebas yang akan diuji untuk mengetahui pengaruhnya terhadap variabel terikat, maka proses analisis regresi yang dilakukan adalah menggunakan analisis regresi berganda. Menurut Sugiyono (2013:277) mendefinisikan bahwa: "Analisis regresi ganda digunakan oleh peneliti, bila peneliti bermaksud meramalkan bagaimana keadaan (naik turunnya) variabel dependen (kriterium), bila dua atau lebih variabel independen sebagai faktor prediktor dimanipulasinya (dinaikturunkannya)". Persamaan regresi berganda untuk dua prediktor yang ditetapkan adalah sebagai berikut:

$$
Y=\alpha+b 1 x 1+b 2 x 2+e
$$

Keterangan :

$\begin{array}{ll}Y & : \text { Produktivitas } \\ \alpha & : \text { Koefesien konstanta } \\ \text { b1b2 } & : \text { Koefesien regresi } \\ x 1 & : \text { Penilaian kinerja } \\ x 2 & : \text { Motivasi } \\ e & : \text { Tingkat kesalahan (error) }\end{array}$

\section{Uji Hipotesis}

a. Uji t

Pengujian yang dilakukan adalah uji parameter (uji korelasi) dengan menggunakan uji $t$ statistik. hal ini membuktikan apakah terdapat pengaruh antara masing-masing variabel independen $(X)$ dan variabel dependen $(Y)$. Menurut Sugiyono (2013:250) menggunakan rumus:

Keterangan :

$$
t=\frac{r \sqrt{n-2}}{\sqrt{1-r^{2}}}
$$

$\mathrm{t}$ : Nilai uji $\mathrm{t}$

$r \quad$ : Koefisien korelasi

$r^{2}$ : Koefisien determinasi

$n$ : Jumlah sampel 
Hasil perhitungan ini selanjutnya dibandingkan dengan $\mathrm{t}_{\text {tabel }}$ dengan menggunakan tingkat kesalahan 0,05 dengan kriteria sebagai berikut :

- $\mathrm{H}_{\mathrm{o}}$ diterima bila $\mathrm{t}_{\text {hitung }}<\mathrm{t}_{\text {tabel }}$

- $\mathrm{H}_{\mathrm{o}}$ ditolak bila $\mathrm{t}_{\text {hitung }}>\mathrm{t}_{\text {tabel }}$

Jika hasil pengujian statistik menunjukkan $\mathrm{H}_{\mathrm{o}}$ ditolak, maka berarti variabel-variabel independen secara parsial mempunyai pengaruh yang signifikan terhadap produktivitas pegawai pada Badan Kepegawaian Daerah dan Pengembangan Sumber Daya Manusia Kabupaten Kepahiang. Tetapi bila $\mathrm{H}_{\mathrm{o}}$ diterima, maka variabel-variabel independen tersebut tidak mempunyai pengaruh signifikan terhadap produktivitas Pegawai Pada badan Kepegawaian Daerah dan Pengembangan Sumber Daya Manusia Kabupaten kepahiang.

\section{b. Uji F (Simultan)}

Pengujian yang dilakukan ini adalah dengan uji parameter $\beta$ (uji korelasi) dengan menggunakan uji $F$-statistik. Untuk menguji pengaruh variabel bebas secara bersama-sama (simultan) terhadap variabel terikat digunakan uji $F$. Menurut Sugiyono (2013:257) dirumuskan sebagai berikut:

$$
\mathrm{F}_{\mathrm{h}}=\frac{R^{2} / k}{\left(1-R^{2}\right) /(n-k-1)}
$$

Keterangan :

$\mathrm{F}_{\mathrm{h}}$ : Nilai Uji F

$\mathrm{R}^{2}$ : Koefisien korelasi berganda

$\mathrm{n} \quad$ : Jumlah anggota sample

$\mathrm{k} \quad$ : Jumlah variabel independen

Distribusi $\mathrm{F}$ ini ditentukan oleh derajat kebebesan pembilang dan penyebut, yaitu, $k$ dan $n$ $\mathrm{k}-1$ dengan menggunakan tingkat kesalahan 0,05 . Untuk uji F, Kriteria yang dipakai adalah :

- $\mathrm{H}_{\mathrm{o}}$ diterima bila $\mathrm{F}_{\text {hitung }}<\mathrm{F}_{\text {tabel }}$

- $\mathrm{H}_{\mathrm{o}}$ ditolak bila $\mathrm{F}_{\text {hitung }}>\mathrm{F}_{\text {tabel }}$

Bila $\mathrm{H}_{\mathrm{o}}$ diterima, maka dapat diartikan bahwa tidak signifikannya suatu variabel-variabel independen secara bersama-sama atas suatu variabel dependen.Sedngkan bila $\mathrm{H}_{\mathrm{o}}$ ditolak berarti menunjukkan adanya pengaruh yang signifikan dari variabel-variabel independen secara bersama-sama terhadap suatu variabel dependen.

\section{HASIL PENELITIAN DAN PEMBAHASAN}

Dalam penelitian ini terdapat 32 orang responden dan untuk mengetahui karakteristik responden tersebut maka dapat diuraikan sebagai berikut :

a. Karakteristik responden berdasarkan Jenis kelamin

Jenis kelamin responden menjadim 2 kelompok yaitu pria dan wanita dan berdasarkan hasil penelitian dilapangan di peroleh hasil 
Tabel 1.

Karakteristik Responden berdasarkan jenis kelamin

\begin{tabular}{|c|c|c|}
\hline Jenis kelamin & Jumlah responden & Persentase \\
\hline Laki-laki & 14 & $44 \%$ \\
\hline Perempuan & 18 & $56 \%$ \\
\hline Total & 32 & $100 \%$ \\
\hline
\end{tabular}

Dari table di atas dapat diketahui bahwa pegawai PNS pada Badan kepegawaian Daerah dan pengembangan Sumber Daya Manusia Kabupaten Kepahiang yaitu laki-laki sebanyak 14 orang atau $44 \%$ sedangkan perempuan 16 orang atau $56 \%$

Tabel 2

Karakteristik Responden Berdasarkan Pendidikan

\begin{tabular}{|c|c|c|}
\hline Pendidikan & Jumlah Responden & Persentase \\
\hline D3 & 2 & $6 \%$ \\
\hline S1 & 27 & $85 \%$ \\
\hline S2 & 3 & $9 \%$ \\
\hline Total & 32 & $100 \%$ \\
\hline
\end{tabular}

Dari tabel diatas terlihat bahwa pendidikan responden terbanyak asalah S1 berjumlah 27 orang atau 85\%, S2 sebanyak 3 orang atau $9 \%$ dan paling sedikit D3 sebanyak 2 orang atau $6 \%$.

Uji Instrumen Peneklitian

1. Uji Validitas

Menurut Sugiono (2013:187) uji validitas dilakukan umtuk mengukur sah atau valid tidaknya suatu kuesioner . suatu item dikatakan valid jika pernyataan pada koesioner mampu untuk mengungkapkan sesuatu yang akan diukur oleh kuesioner tersebut agar data yang diperoleh bisa relevan dengan tujuan uji validitas yang digunakan adalah dengan cara menghitung korelasi antara skor masing-masing butir pertanyaan dengan skor setiap konstruknya.Pengujian ini menggunakan metode Korelasi Pearson Product Moment, dimana peneliti ingin membuktikan keberadaan hubungan antara variable $\mathrm{x}$ dan y, jika korelasi skor masing-masing butir pernyataan setiap konstruknya akan dikatakan valid apabila signifikan pada level 0,05

2. Uji Validitas Motivasi

Dimana menggambarkan hasil uji validitas variable motivasi dengan menggunakan Uji korelasi Pearson Product Moment

3. Uji Validasi Produktivitas

Dimana menggambarkan hasil uji validitas variable produktivitas pegawai dengan menggunakan Uji korelasi Pearson Product Momen 


\section{HASIL DAN PEMBAHASAN}

\section{Analisis Korelasi dan Regresi}

a. Analisis Korelasi Ganda

Analisis kolerasi ganda didasari atas pengaruh satu variabel independen dengan satu variabel dependen.Menurut Sugiyono (2009: 261-262), Apabila analisis korelasi ganda sederhana didasari atas hubungan fungsional atau kausal satu variabel independen dengan satu variabel dependen, maka analisis korelasi ganda didasari atas hubungan fungsional atau kausal dua atau lebih variabel independen dengan satu variabel dependen. Pada penelitian ini ada dua variabel bebas sehingga menurut Sugiyono (2009: 275)

Tabel 3

Hasil Koefisien Korelasi

\begin{tabular}{|l|l|}
\hline Nilai Korelasi $(\mathbf{R})$ & $\mathbf{R}$ Square $\left(\mathbf{R}^{\mathbf{2}}\right)$ \\
\hline 0,688 & 0,474 \\
\hline
\end{tabular}

Tabel diatas menggambarkan hubungan antara Penilaian Kinerja dan Motivasi dengan Produktivitas Pegawai.Nilai Korelasi $(\mathrm{R})$ antara Penilaian Kinerja $\left(\mathrm{X}_{1}\right)$ dan Motivasi $\left(\mathrm{X}_{2}\right)$ dengan Produktivitas Pegawai (Y) adalah 0,688. Karena nilai tersebut berada antara 0,60-0,799 maka hubungan tersebut dikatakan kategori kuat.

Nilai Koefisien Determinasi $\left(\mathrm{R}\right.$ Square $=\mathrm{R}^{2}$ ) antara Penilaian Kinerja $\left(\mathrm{X}_{1}\right)$ dan Motivasi $\left(\mathrm{X}_{2}\right)$ dengan Produktivitas Pegawai (Y) adalah 0,474. Artinya kontribusi variabel Penilaian Kinerja $\left(\mathrm{X}_{1}\right)$ dan Motivasi $\left(\mathrm{X}_{2}\right)$ dalam mempengaruhi Produktivitas Pegawai $(\mathrm{Y})$

\section{b. Analisis Regresi Berganda}

Menurut sugiyono (2013:277) Analisis regresi berganda digunakan oleh peneliti, bila penelitibermaksud meramalkan bagaimana keadaan (naik turunnya) variabel dependen (kriterium), bila dua atau lebih variabel independen sebagai faktor prediktor dimanipulasinya (dinaik-turunkannya).

Tabel 4.

Hasil uji regresi berganda

\begin{tabular}{|c|c|c|}
\hline Variabel & B & Nilai p (Sig.) \\
\hline Constanta & 3,462 & 0,603 \\
\hline Penilaian Kinerja & 0,405 & 0,032 \\
\hline Motivasi & 0,495 & 0,014 \\
\hline
\end{tabular}

Berdasarkan tabel diatas diperoleh persamaan regresi linear berganda antara Penilaian Kinerja dan Motivasi dengan Produktivitas Pegawai, yaitu:

$$
\begin{aligned}
& Y=a+b 1 \times 1+b 2 \times 2 \\
& Y=3,462+0,405 X_{1}+0,495 X_{2}
\end{aligned}
$$

Dimana :

$\mathrm{Y}=$ Produktivitas Pegawai

$\alpha=$ Konstanta

$\mathrm{X}_{1}=$ Penilaian Kinerja

$\mathrm{X}_{2}=$ Motivasi 
Konstanta regresi sebesar 11,766 menyatakan bahwa ketika tidak ada variabel Penilaian Kinerja dan Motivasi maka skor Produktivitas Pegawai adalah sebesar 11,766 atau 12 (dibulatkan).

\section{Uji Hipotesis}

a. Uji t (Parsial)

Pengujian yang dilakukan adalah uji parameter (uji korelasi) dengan menggunakan uji $t$ statistik. Hal ini membuktikan apakah terdapat pengaruh antara masing-masing variabel independen $(X)$ dan variabel dependen $(Y)$. Menurut Sugiyono (2013:250)

Tabel 5

Hasil uji t

\begin{tabular}{|c|c|c|}
\hline Variabel & t-hitung & Nilai p (Sig.) \\
\hline Penilaian Kinerja & 2,258 & 0,032 \\
\hline Motivasi & 2,612 & 0,014 \\
\hline
\end{tabular}

Untuk mengetahui pengaruh masing-masing variabel independent (Penilaian Kinerja dan Motivasi) terhadap variabel dependent (Produktivitas Pegawai) dilakukan dengan menggunakan Uji t.

1. Pengaruh Penilaian Kinerja terhadap Produktivitas Pegawai

Dari tabel diatas diperoleh nilai $\mathrm{t}=2,258$ dengan nilai $\mathrm{p}=0,032$. Karena nilai $\mathrm{p}<0,05$ maka secara statistik dapat dikatakan bahwa ada pengaruh yang signifikan antara Penilaian Kinerja terhadap Produktivitas Pegawai pada Badan Kepegawaian Daerah dan Pengembangan Sumber Daya Manusia Kabupaten Kepahiang.

2. Pengaruh Motivasi terhadap Produktivitas Pegawai

Dari tabel diatas diperoleh nilai $t=2,612$ dengan nilai $p=0,014$. Karena nilai $p<0,05$ maka secara statistik dapat dikatakan bahwa ada pengaruh yang signifikan antara Motivasi terhadap Produktivitas Pegawai pada Badan Kepegawaian Daerah dan Pengembangan Sumber Daya Manusia Kabupaten Kepahiang.

b. Uji F (simultan)

Pengujian yang dilakukan ini adalah dengan uji parameter $\beta$ (uji korelasi) dengan menggunakan uji $F$-statistik. Untuk menguji pengaruh variabel bebas secara bersama-sama (simultan) terhadap variabel terikat digunakan uji F. Menurut Sugiyono (2013:257)

Tabel 6

Hasil uji F

\begin{tabular}{|c|c|}
\hline F-hitung & Nilai p (Sig.) \\
\hline 13,062 & 0,000 \\
\hline
\end{tabular}

Dari uji ANOVA atau F test, didapat nilai $F$ hitung adalah 13,062 dengan nilai $p=0,000$. Karena nilai $\mathrm{p}<0,05$ maka model regresi dapat dipakai untuk memprediksi Produktivitas Pegawai dengan kata lain ada pengaruh secara bersama-sama (simultan) antara Penilaian Kinerja dan Motivasi dengan Produktivitas Pegawai pada Badan Kepegawaian Daerah dan Pengembangan Sumber Daya Manusia Kabupaten Kepahiang. 


\section{Pembahasan}

1. Pengaruh Penilaian Kinerja terhadap Produktivitas Pegawai pada Badan Kepegawaian Daerah dan Pengembangan Sumber Daya Manusia Kabupaten Kepahiang

Penilaian kinerja merupakan suatu sistem yang dilakukan secara periodik untuk meninjau dan mengevaluasi kinerja individu. Penilaian kinerja merupakan suatu pedoman yang diharapkan dapat mewujudkan prestasi kerja para karyawan secara rutin dan teratur. Sehingga dapat memberikan manfaat bagi pemberian kompensasi dan pengembangan karir karyawan, Kasmir (2018:184).

Berdasarkan hasil pengujian statistik dalam penelitian pengaruh penilaian kinerja terhadap produktivitas pegawai pada Badan Kepegawaian Daerah dan Pengembangan Sumber Daya Manusia Kabupaten Kepahiang diperoleh nilai $t_{\text {hitung }}=2,258>$ nilai $t_{\text {tabel }}=$ 2,045 dan nilai $\mathrm{p}$ (sig.) $0,036<0,05$, yang berarti secara statistik $\mathrm{H} 1$ ditolak dan artinya terdapat pengaruh positif dan signifikan antara penilaian kinerja terhadap produktivitas.

Hal ini berarti sesuai dengan hipotesis H1 yang berbunyi diduga penilaian kinerja berpengaruh positif dan signifikan terhadap produktivitas kerja pegawai pada Badan Kepegawaian Daerah dan Pengembangan Sumber daya Manusia Kabupaten Kepahiang.

2. Pengaruh Motivasi terhadap Produktivitas Pegawai pada Badan Kepegawaian Daerah dan Pengembangan Sumber Daya Manusia Kabupaten Kepahiang.

Menurut Nirman (2005:47) motivasi adalah keadaan dimana usaha dan kemauan keras seseorang diarahkan kepada pencapaian hasil tertentu, seperti produktivitas, kehadiran atau prilaku kerja kreatifnya. Sedangkan Menurut Adair (2007:192) motivasi adalah apa yang membuat orang melakukan sesuatu, dan juga dapat membuat orang benar-benar berusaha mengeluarkan energi demi apa yang mereka lakukan agar mencapai tujuan yang diinginkan.

Berdasarkan hasil pengujian statistik dalam penelitian pengaruh motivasi terhadap produktivitas pegawai pada Badan Kepegawaian Daerah dan Pengembangan Sumber Daya Manusia Kabupaten Kepahiang ini diperoleh nilai $t_{\text {hitung }}=2,612>$ nilai $t_{\text {tabel }}=2,045$ dan nilai p (sig.) $0,008<0,05$, yang berarti bahwa $\mathrm{H} 2$ ditolak dan artinya terdapat pengaruh positif dan signifikan antara motivasi terhadap produktivitas. Hal ini berarti sesuai dengan hipotesis Ho2 yang berbunyi diduga motivasi berpengaruh positif dan signifikan terhadap produktivitas pegawai.

3. Pengaruh Penilaian Kinerja dan Motivasi terhadap Produktivitas Pegawai pada Badan Kepegawaian Daerah dan Pengembangan Sumber Daya Manusia Kabupaten Kepahiang.

Produktivitas adalah menghasilkan atau meningkatkan hasil barang setinggi mungkin dengan memanfaatkan sumber daya secara efesien. Oleh karena itu produktivitas sering diartikan sebagai rasio antara keluaran dan masukan dalam satuan waktu tertentu, Blecher dalam Wibowo (2007: 109)

Variabel penilaian kinerja dan motivasi sama-sama berpengaruh terhadap produktivitas pegawai. Dalam hal ini berarti produktivitas pegawai dipengaruhi oleh penilaian kinerja dan motivasi. Penilaian kinerja dan motivasi yang lakukan dan diberikan oleh perusahaan berpengaruh terhadap produktivitas pegawai dalam mencapai target dalam melaksanakn pekerjaanya. 
Dari uji F (simultan) statistik dalam penelitian pengaruh penilaian kinerja terhadap produktivitas pegawai pada Badan Kepegawaian Daerah dan Pengembangan Sumber Daya Manusia Kabupaten Kepahiang ini diperoleh nilai $F_{\text {hitung }}=13,062>F_{\text {tabel }}=3,33$ dan nilai $p$ (sig.) $0,000<0.05$, yang berarti bahwa Ho3 ditolak dan artinya terdapat pengaruh positif dan signifikan antara penilaian kinerja dan motivasi terhadap produktivitas.

Hal ini berarti sesuai dengan hipotesis $\mathrm{H} 3$ yang berbunyi diduga penilaian kinerja dan motivasi berpengaruh positif dan signifikan terhadap produktivitas pegawai pada Badan Kepegawaian Daerah dan Pengembangan Sumber daya Manusia Kabupaten Kepahiang.

\section{SIMPULAN} berikut:

Berdasarkan hasil penelitian dan pembahasan, maka dapat diambil kesimpulan sebagai

1. H1 ditolak kerana diperoleh nilai artinya terdapat pangaruh positif dan signifikan antara penilaian kinerja $\left(\mathrm{X}_{1}\right)$ dengan produktivitas $(\mathrm{Y})$ pegawai pada Badan Kepegawian Daerah dan Pengembangan Sumber Daya Manusia Kabupaten Kepahiang.

2. H2 ditolak karena diperoleh nilai yang berarti terdapat pengaruh positif dan signifikan antara motivasi $\left(\mathrm{X}_{2}\right)$ terhadap produktivitas $(\mathrm{Y})$ pegawai pada Badan Kepegawaian Daerah dan Pengembangan Sumber Daya Manusia Kabupaten kepahiang.

3. H3 ditolak Karena berdasarkan uji statistik dikatahui bahwa ada pengaruh penilaian kerja $\left(\mathrm{X}_{1}\right)$ dan motivasi $\left(\mathrm{X}_{2}\right)$ terhadap produktivitas $(\mathrm{Y})$ pegawai pada Badan Kepegawaian Daerah dan Pengembangan Sumber Daya Manusia Kabupaten Kepahiang.

4. Nilai $\mathrm{R}^{2}$ Artinya kontribusi variabel Penilaian Kinerja $\left(\mathrm{X}_{1}\right)$ dan Motivasi $\left(\mathrm{X}_{2}\right)$ dalam mempengaruhi Produktivitas Pegawai (Y)

Berdasarkan kesimpulan di atas, maka dapat diberikan beberapa saran diharapkan Kantor Badan Kepegawaian Daerah dan Pengembangan Sumber Daya Manusia Kabupaten kepahiang dapat terus melakukan penilaian kinerja terhadap pegawainya secara optimal sehingga progres kinerja pegawai akan terus terpantau apakah meningkat atau menurun setiap periodenya, dan dapat meningkatkan motivasi dalam bekerja sehingga hasilnya dapat berupa kinerja organisasi dapat tercapai dan ditingkatkan untuk penilaian kinerja serta motivasi kerja dari atasan atau instansi terkait agar terbentuk karakter pegawai yang lebih baik.

\section{DAFTAR PUSTAKA}

Adair, Jhon.(2007).PemimpinYang Bepusat Pada Tindakan. Jakarta : Binarupa Aksara. Asri. (2014). Pengaruh Penilaian Kinerja dan Motivasi Kerja Karyawan Terhadap Produktivitas Kerja Karyawan Pada Divisi Manajemen Sumber Daya Manusia di PT. Inti (Persero).Bandung

Blecher dalam Wibowo (2007) Perilakalu Dalam Organisasi,Jakarta : Rajawali Pers

Hasibuan (2006). Manajemen Dasar, Pengertian Dan Masalah. Edisi Revisi. Jakarta : Bumi Aksara

Kasmir. (2018). Manajemen Sumber DayaManusia (teori dan praktik). Depok : Raja Grafindo Persada.

Maslow dalam Juni (2017) Pengaruh Motivasi terhadap kinerja Karyawan. Jakarta : Salemba Empat 
Nirman, Umar. (2005). Perilaku Organisasi. Surabaya : Citra Media.

Purwanto. (2006). Managemen dan Organisasi, Bandung : Remaja Rosda karya

Robbins. (2009) Perilaku Organisasi, Jakarta : Salemba empat

Sedarmayanti. (2009) Sumber Daya Manusia dan Produktivitas kerja. Bandung

Simamora (2006) Manjemen Sumber Daya Manusia, Depok : Raja Grafindo Persada

Sugiyono (2013) Metodelogi penelitian Kuantitatif, kualitatif dan $R \& D$,Bandung. ALFABETA

Wibowo. (2007). Manajemen Kinerja. Jakarta : Raja Grafindo Persada. 